\title{
A negociação do acesso ao Benefício de Prestação Continuada por crianças com Síndrome Congênita do Zika Vírus em Pernambuco
}

Negotiation of access to the Continuing Care Benefit by children with Congenital syndrome of Zika Virus in Pernambuco

Silvana Sobreira de Matos, Marion Teodósio de Quadros e Ana Cláudia Rodrigues da Silva

\section{(2) OpenEdition Journals}

\section{Edição electrónica}

URL: http://journals.openedition.org/aa/3993

DOI: 10.4000/aa.3993

ISSN: 2357-738X

\section{Editora}

Programa de Pós-Graduação em Antropologia Social (UnB)

\section{Edição impressa}

Data de publição: 1 dezembro 2019

Paginação: 229-260

ISSN: 0102-4302

\section{Refêrencia eletrónica}

Silvana Sobreira de Matos, Marion Teodósio de Quadros e Ana Cláudia Rodrigues da Silva, «A negociação do acesso ao Benefício de Prestação Continuada por crianças com Síndrome Congênita do Zika Vírus em Pernambuco», Anuário Antropológico [Online], v.44 n.2 | 2019, posto online no dia 02 dezembro 2019, consultado o 27 abril 2021. URL: http://journals.openedition.org/aa/3993 ; DOI: https://doi.org/10.4000/aa.3993

\section{(c) (i) (9)}

Anuário Antropológico is licensed under a Creative Commons Atribuição-Uso Não-Comercial-Proibição de realização de Obras Derivadas 4.0 International. 


\section{A negociação do acesso ao Benefício de Prestação Continuada por crianças com Síndrome Congênita do Zika Vírus em Pernambuco ${ }^{1}$} Negotiation of access to the Continuing Care Benefit
by children with Congenital Syndrome of Zika Virus in
Pernambuco

Silvana Sobreira de Matos, Marion Teodósio de Quadros e Ana Cláudia Rodrigues da Silva Universidade Federal de Pernambuco - Brasil

\section{Introdução}

O Estado de Emergência em Saúde Pública decorrente da epidemia do Zika vírus no Brasil mobilizou o sistema de saúde, a assistência social, o campo científico e jurídico, num esforço conjunto para responder à população e às agências internacionais sobre o nascimento de crianças com microcefalia (Síndrome Congênita do Zika - SCZ). Esta nova condição de saúde, diferentemente de outras deficiências, acabou por receber de todos os entes federados um status diferenciado. Leis foram criadas e portarias sancionadas de forma emergencial. Uma dessas leis foi a que priorizou o acesso ao Benefício de Prestação Continuada (BPC), por crianças acometidas pelo Zika vírus no Instituto Nacional do Seguro Social (INSS).

Passados mais de 3 anos do boom de casos de microcefalia (SCZ), os familiares dessas crianças têm percebido que a condição delas é duradoura, e que o BPC destinado à pessoa com deficiência não atende às necessidades e nem às especificidades de uma deficiência que foi gerada, segundo o discurso das famílias, por negligência do Brasil em promover políticas efetivas de saneamento básico, acesso a água potável e controle do vetor da Zika (Aedes Aegypti).

A pesquisa "Etnografando cuidados e Pensando Políticas de Saúde e Gestão de Serviços para Mulheres e Seus Filhos com Distúrbios Neurológicos Relacionados com Zika em Pernambuco, Brasil”’ vem, desde 2016, acompanhado as políticas públicas implementadas pelo Estado de Pernambuco e Federação, as famílias atingidas pela SCZ, os diversos itinerários realizados na busca de cuidados para seus filhos, seja em suas associações, na saúde e assistência social, no judiciário, 
ou no INSS. Esta pesquisa tem como coordenador geral o Professor Russell Parry Scott (UFPE) e faz parte do edital de junho de 2016, de âmbito federal, intitulado "Prevenção e Combate ao vírus Zika". Sessenta e nove projetos foram aprovados e dentre estes somente "Etnografando Cuidados", do qual fazemos parte, tem um viés antropológico e etnográfico, voltado para o entendimento dos impactos da SCZ nas famílias atingidas e a análise das políticas públicas implementadas por Pernambuco. Em julho de 2016, outro edital foi lançado em Pernambuco, o "Institutional Links - Vírus Zika” com recursos provenientes do Newton Fund no Brasil. Nesse edital, três projetos foram aprovados, dois que versam sobre aplicativos tecnológicos, e o terceiro, do qual fazemos parte, tem a antropologia e a etnografia das famílias e das políticas públicas em SCZ como foco. Está dividido em dois eixos temáticos: o primeiro analisa a experiência da SCZ nas famílias atingidas e o eixo 2, busca compreender como o Estado (Saúde e Assistência Social), a pesquisa científica e o judiciário se organizaram para responder à Emergência em Saúde Pública em decorrência do Zika. A pesquisa conta ainda com duas pesquisadoras de pós-doutorado, Silvana Matos e Luciana Lira, além de bolsistas de doutorado e iniciação científica.

Com a aprovação pelo Comitê de Ética da UFPE (Número do Parecer: 2.001.642), em abril de 2017, começamos o levantamento de dados que subsidiam o presente artigo. Todas as entrevistas foram precedidas pela leitura do Termo de Consentimento Livre e Esclarecido (TCLE).

O trabalho de campo resultou em entrevistas semiestruturadas e diários de campo que forneceram subsídios para o presente artigo. Com relação à metodologia do Eixo 1, optamos por seguir, juntamente com as famílias atingidas pela SCZ, os itinerários terapêuticos que estas realizam, levando em consideração um itinerário ampliado (Alves, 2015; Pinho; Pereira, 2012), ou seja, para além dos hospitais e da reabilitação (em suas casas, aniversários, igrejas, audiências públicas, nas suas associações (União de Mães de Anjos/UMA, Aliança das Mães e Famílias Raras/AMAR, etc.). Com relação ao eixo 2, optamos por fazer trabalho de campo nas Secretarias Municipais e Estaduais de Saúde e Assistência Social, na Defensoria Pública Estadual, da União e Ministério Público Estadual de Pernambuco, no INSS, na Frente Parlamentar em Defesa da Pessoa com Deficiência, em Audiências Públicas (Câmara dos Deputados Estaduais de Pernambuco), na Frente Nacional na luta pelos direitos da pessoa com a Síndrome Congênita do Zika (FNLDPSCZ), no Ministério do Desenvolvimento Social (MDS/Brasília), nos hospitais e centros de reabilitação, em grupos de pesquisa diversos que estudam a SCZ, além da participação em grupos de WhatsApp. 
Até outubro de 2019, a pesquisa Etnografando Cuidados realizou 119 entrevistas, 50 com as famílias atingidas (mães, pais, tias, avós) e 69 com gestores, técnicos, profissionais da saúde, assistência social, judiciário e pesquisadores em SCZ. Essas entrevistas foram concretizadas em diversos locais de Pernambuco e do Brasil entre abril de 2017 e setembro de 2019. As entrevistas foram editadas para garantir o anonimato e foram usados pseudônimos ou apenas a profissão de alguns dos entrevistados. Além das entrevistas, realizamos diversas gravações em áudio e vídeo de reuniões, audiências públicas, salas de situação, palestras, seminários e congressos.

A partir desse contexto, este artigo tem como propósito discutir qual pessoa com deficiência merece proteção do Estado. Os dados analisados são resultado de observações, conversas informais e entrevistas em diversos espaços, tais como a Secretaria Estadual de Saúde e Secretaria Estadual de Assistência Social do Estado de Pernambuco, Instituto de Nacional de Seguro Social (INSS), Aliança das Mães e Famílias Raras (AMAR), União Mãe de Anjos (UMA), em reunião da Frente Nacional na luta pelos direitos da pessoa com a Síndrome Congênita do Zika (FNLDPSCZ ) ${ }^{3}$, com o Ministério de Desenvolvimento Social (MDS) em março de 2017 e, principalmente, com as famílias que têm filhos com a SCZ.

Neste sentido, para melhor compreensão dos objetivos desta proposta, o artigo será dividido em três partes, além da introdução e das considerações finais. Na primeira parte discutiremos sobre Emergência em Saúde Pública, Deficiência e SCZ, e em seguida debateremos sobre o modelo social de deficiência e sua influência no BPC e por fim analisaremos as contradições no acesso a esse benefício pelas famílias atingidas pela SCZ. Nosso argumento é que a deficiência tem sido relativizada em detrimento do critério de pobreza e que embora o Estado venda a ideia de uma “prioridade da prioridade" no acesso ao BPC para as famílias atingidas pelo SCZ, essa ideia não é efetivada quando observamos as diversas contradições e impedimentos ao seu acesso.

\section{Deficiência, síndrome congênita do Zika vírus e emergência em saúde pública}

Em 2015, o Brasil vivenciava grave crise política em torno do impeachment da Presidenta Dilma Rousseff, afetando diversos setores da administração governamental no país, ao mesmo tempo em que experimentava uma crise na saúde, decorrente da tríplice epidemia de Dengue, Chikungunya e Zika. No segundo semestre de 2015, a neuropediatra Vanessa Van der Linden, de Recife, Pernam- 
buco, percebia um aumento exponencial de crianças nascidas com microcefalia com causa desconhecida, no qual exames de rotina se apresentavam negativados para as etiologias existentes, como explicou a neuropediatra à pesquisadora Debora Diniz (2016a).

Comunicando o fato imediatamente à Secretaria Estadual de Saúde de Pernambuco, em reunião no dia 14 de outubro de 2016, Vanessa Van der Linden começou a investigar, entre os dias 19 e 22 de outubro de 2015, os recém-nascidos com microcefalia, em cooperação com especialistas do Instituto de Medicina Integral Professor Fernando Figueira (IMIP), do Hospital Agamenon Magalhães (HAM), do Centro Integrado de Saúde Amaury de Medeiros (CISAM), do Hospital Universitário Oswaldo Cruz (HUOC), além do médico Carlos Brito, especialista em arboviroses. Esse foi, portanto, o primeiro inquérito de pesquisa sobre microcefalia e vírus Zika executado no Brasil (Diniz, 2016a).

Como exemplifica Debora Diniz (2016a), esta epidemia mobilizou pesquisadores, intelectuais e clínicos, e estes, no que ela chamou de médicos de beira de leito, se tornaram peças-chave no panorama da ciência mundial, tanto pela rapidez com que notificaram os casos, levantaram hipóteses e comunicaram seus achados em artigos e estudos clínicos.

O Ministério da Saúde, percebendo a gravidade da situação, enviou a Recife, em outubro de 2015, uma missão da vigilância em saúde federal acompanhada pela Organização Pan-Americana de Saúde (Opas) (Diniz 2016a).

Quase três meses após a declaração da Emergência em Saúde Pública de importância Nacional (ESPIN) pelo Brasil, Margareth Chan, diretora-geral da Organização Mundial de Saúde (OMS), convocou o Comitê de Emergência em conformidade com o Regulamento Sanitário Internacional (RSI) e declarou Emergência de Saúde Pública de Importância Internacional (ESPII), em $1^{\circ}$ de fevereiro de 2016, pela gravidade das ocorrências no Brasil. Estes acontecimentos impactaram de forma contundente a ciência, os Estados e países, as políticas públicas, as famílias atingidas e as noções de deficiência e emergência em saúde pública.

É importante destacar que a última ESPII havia sido declarada pela OMS em 2014 em decorrência do Ebola. Para alguns pesquisadores (Ventura, 2016) e técnicos, como Enrique Vazquez, da OPAS, existia a interpretação de "[...] que a OMS ficou um pouco ferida do Ebola porque a resposta não foi ótima, a OMS demorou”4.

Há três especificidades importantes na Emergência de Saúde Pública de Importância Internacional (ESPII) relacionada ao Zika vírus que é preciso evidenciar. Em 
primeiro lugar, deve ser considerado que até hoje a OMS declarou quatro ESPIIs. As três primeiras, a Gripe A (H1N1) em 2009, o Poliovírus em 2014, e o Ebola em 2014, foram declaradas a partir de um conjunto de informações pretéritas sobre estas etiologias, suas formas de propagação e prevenção. Para a ESPII do Zika, a comunidade científica internacional desconhecia inclusive que esse vírus poderia causar comprometimentos neurológicos nos fetos e nos bebês de mães que foram acometidas pelo Zika vírus durante a gestação. Alguns autores destacaram que a diferença entre as declarações de emergência para o Ebola e para o Zika residia no fato de que, no primeiro caso, a emergência foi declarada pelo que já se sabia sobre a doença e, no segundo caso, pelo que não se sabia (Heymann et al., 2016; Garcia, 2018; Bueno, 2017).

Em segundo lugar, diferentemente das demais ESPIIs declaradas, a do Zika vírus foi a única na qual as consequências geraram o nascimento de crianças com deficiência, o que aproxima a experiência com a SCZ a acontecimentos como a epidemia de Rubéola e ao pânico em decorrência da relação entre à malformação fetal devido ao remédio Talidomida, na Europa e nos EUA, nos anos 1960.

Em terceiro lugar, estes fatos, uma emergência declarada com base no desconhecimento sobre a etiologia e suas consequências que resultavam no nascimento de crianças com deficiência reconfiguraram não só as políticas públicas, mas também os estudos científicos sobre deficiência. Emergência de Saúde Pública de Importância Internacional e deficiência nunca havia sido uma equação possível, e o resultado foi a marcação socioepidemiológica de uma certa "anormalidade" e excepcionalidade dessas crianças para a ciência, as políticas públicas e a população.

O Brasil e, mais especificamente, o Estado de Pernambuco foi inundado por diversas pesquisas e pesquisadores de distintas áreas, além das mídias nacionais e internacionais, que buscavam compreender o fenômeno, ao passo que fomentavam também esse caráter "anormal” e extraordinário das crianças com SCZ. Neste cenário superpovoado de estudos científicos e de exposição exacerbada destas crianças e suas famílias, é muito recorrente escutarmos de uma parcela de mães que seus filhos não são ratos de laboratório, que elas não querem mais ser pesquisadas, que todos estão ganhando fama e dinheiro enquanto elas continuam na mesma situação de vulnerabilidade social e econômica.

Neste sentido, estes surtos globais, e mais especificamente para o caso do Zika vírus, demonstraram que estas epidemias produziram novas precarizações em vidas já vulnerabilizadas pela desigualdade social (Diniz, 2016a; 2016b; 2017). No con- 
texto do Zika Vírus, as mulheres foram atingidas de maneira ampla, já que a contenção do risco e, sobretudo, a cobrança de prevenção foi direcionada a elas (Silva; Matos; Quadros, 2017, p. 225). Assim, a estratégia fortemente propagada na erradicação do mosquito Aedes Aegypti - "Mosquito bom é mosquito morto" (Pimenta, 2016; Ventura, 2016; Silva; Matos; Quadros, 2017) - acabou por obscurecer ainda mais, num primeiro momento, o debate sobre os determinantes sociais da epidemia do Zika (Nunes; Pimenta, 2016; Silva; Matos; Quadros, 2017) e todo um debate sobre transmissão sexual do vírus Zika, direitos reprodutivos e aborto (Carvalho, 2017; Nunes; Pimenta, 2016; Galli; Deslandes, 2016, Scott et al., 2017). Em decorrência disso, tem crescido nas associações de apoio a mães e cuidadores de crianças com SCZ, bem como entre as famílias atingidas, o aumento gradativo das discussões sobre ética em pesquisa e vida em experimentação (Matos; Silva; Quadros, 2018; Matos, 2018).

Estas famílias, embora reconheçam a importância de algumas pesquisas, não deixam de se ressentir com o fato de seus filhos serem tratados de forma instrumental. Segundo alguns relatos de mães, seus filhos não são apenas uma amostra de sangue, urina, saliva ou objeto de investigação científica, tudo isso porque, geralmente, os pesquisadores não dão um feedback sobre os resultados dos exames e achados clínicos nos seus filhos, cabendo a elas a informação somente depois da publicação dos artigos científicos ou das matérias nos veículos de comunicação (Matos; Silva; Quadros, 2018).

Já no que diz respeito a esta marcação da “anormalidade”, excepcionalidade ou singularidade da SCZ no cotidiano destas famílias, muitas mães relatam os olhares de curiosidade, repulsa e preconceito com seus filhos. Um dos locais onde estes estigmas aparecem é na vizinhança. Segundo Scott et al. (2018, p. 6),

o bairro nem sempre é um local solidário, e o questionamento da própria humanidade do filho e salubridade da mãe não deixa de inquietar a convivência com a vizinhança, muitas vezes calcadas em dicotomias do bem e do mal acirradas por uma religiosidade acusatória que mal sabe conviver com a deficiência. Tais comentários incitam as dúvidas e inseguranças das mães e suas redes, inclusive das suas próprias origens e a transmissão de traços indesejados, provocando não somente conflitos com estes vizinhos, bem como familiares [...]

Mas esta marcação não é restrita apenas à vizinhança e acontece de forma recorrente nos itinerários terapêuticos, que são repletos de consultas e terapias 
de várias especialidades, na busca por cuidados para seus filhos, com trajetos múltiplos e distantes, realizados geralmente de ônibus. Marta é mãe de $\operatorname{Carlos}^{6} \mathrm{e}$ quando perguntada se já havia presenciado algum olhar preconceituoso, respondeu que:

Marta: Ah, mas a gente vê todo dia. Pergunta idiota tem todo o momento.

Luciana Lira: Como você lida com isso?

Marta: Respiro fundo e ignoro.

Luciana Lira: E no início?

Marta: No início eu dava coice, as vezes eu ainda dou. Porque é cada pergunta! "Nhein nhei! Ele é doentinho?", "Que nada, um menino saudável desses é doentinho?”, "Foram para o médico?”, “Não, fomos para piscina”. Assim ironizando, por quê? Pelo amor de Deus, marmininu! Pra essa educação zero, a minha também é zero. Eu comecei a usar, acontecia, aquele paninho que ele era bem esquisitinho. Eu usava boné nesse menino, e quando tirei eram aqueles olhares ${ }^{7}$.

O caráter de excepcionalidade ou singularidade da SCZ também foi incorporado em algumas políticas públicas no Estado de Pernambuco e no Brasil naquilo a que nos referimos em outro artigo como "prioridade da prioridade" (Silva; Matos; Quadros, 2017, 2019). Desde o ano 2000, a pessoa com deficiência no Brasil tem atendimento prioritário garantido pela Lei n 10.048, mas com a ESPII o Estado de Pernambuco instituiu que as crianças com SCZ teriam prioridade de atendimento em saúde e assistência social em relação às outras pessoas com deficiência. Uma das justificativas para este tratamento diferenciado pelo Estado de Pernambuco (além de toda discussão sobre as implicações e resposta a uma ESPII) transparece na fala de uma gestora que enfoca o caráter desconhecido da doença e dos prognósticos destas crianças:

Então é novidade pras mães, é novidade para os profissionais. A gente está há dois anos desse boom, mas assim, a gente ainda se depara com muita novidade. Então, essas crianças são uma caixinha de surpresas. Um dia elas precisam de uma coisa, outro dia estão precisando de outra. E a gente vai tentando adequar a estrutura, a atenção, da forma que a gente pode para melhorar a vida dessas famílias ${ }^{8}$.

Este caráter de excepcionalidade, no discurso que mostramos acima, se reflete em ações práticas e políticas públicas na saúde estadual, principalmente na Central 
de Regulação do Estado, que é responsável por organizar o fluxo de atendimento hospitalar, internações, consultas, procedimentos ambulatoriais (média e alta complexidade), na reabilitação e na criação de setores específicos como a Área Técnica para Vigilância da SCZ e o Núcleo de Apoio as Famílias de Crianças com Microcefalia (NAFCM). Este núcleo foi criado com a função de

escutar as demandas dos apoiadores nas 12 regiões de saúde do Estado de Pernambuco e articular com outros setores da saúde e assistência a execução das demandas. Então assim, nosso papel na verdade é fazer com que essa discussão não se encerre, a gente está o tempo todo provocando os setores e trazendo as demandas e pensando em grupo, em equipe ${ }^{9}$.

Nenhuma outra deficiência, seja auditiva, motora, intelectual, doença rara ou autismo, etc., possui fluxo de atendimento específico (que não seja o fluxo para pessoas com deficiência) ou núcleos exclusivos como o criado para SCZ. Esta política pública, que chamamos de "prioridade da prioridade", é revestida de debate acalorado. Se, por um lado, as famílias que têm filhos com SCZ informam que o fluxo delas deve ser diferenciado em detrimento da negligência do Estado em controlar o vetor do vírus Zika (o mosquito Aedes aegypti), por outro lado, as famílias e associações de mães com filhos com outras deficiências sentem que foram esquecidas mais uma vez (Silva; Matos; Quadros, 2018). Não há consenso sobre esta prioridade nem mesmo entre os gestores de saúde de Pernambuco; alguns deles questionam a criação de uma categoria prioritária dentro da categoria de pessoa com deficiência.

No âmbito federal, esta "prioridade da prioridade" é refletida principalmente em duas portarias: a Portaria n 321 de 14 de julho de 2016 do Ministério das Cidades, que dispensa o sorteio para candidatos ao programa Minha Casa Minha Vida que possuam membro da família com microcefalia; e a Portaria $\mathrm{n}^{\circ} 58$, de 3 de junho de 2016, que dispõe sobre ações articuladas das redes de Assistência Social e Previdência Social na atenção às crianças com SCZ para o acesso ao Benefício de Prestação Continuada da Assistência Social - BPC. Assim, essas duas portarias tratam de questões importantes como o direito a moradia e a garantia da segurança de renda da pessoa com deficiência, direitos esses que foram ganhando força a partir de 1970, quando houve o fortalecimento dos estudos sobre a deficiência, primeiramente no Reino Unido e, em seguida, nos Estados Unidos. Neste sentindo no próximo item discutiremos sobre o modelo social de deficiência e como este modelo influenciou a política que temos como foco neste artigo: o Benefício de Prestação Continuada. 


\section{O modelo social da deficiência e o benefício de prestação continuada}

É importante salientar que a busca por direitos da pessoa com deficiência passou por diversas fases e ao longo da história o corpo da pessoa com deficiência foi submetido a diversas formas de controle. Por muito tempo, a explicação dada fazia menção à deficiência como castigo divino, expressão do azar ou pecado. Com a ascensão dos estudos biomédicos, o corpo com impedimentos passou a ser visto com base na embriologia e na genética, no qual o objetivo maior era normalizá-lo através de cirurgias e da reabilitação (Barbosa; Diniz; Santos, 2010). Desta forma, "o modelo biomédico da deficiência passou a descrever os impedimentos corporais como um desvio da natureza que, expresso na restrição de sentidos, capacidades ou habilidades, deveria ser controlado pelo poder médico" (Barbosa; Diniz; Santos, 2010, p. 44).

As reflexões surgidas na década de 1970 foram marcadas pela ascensão da politização dos movimentos sociais das pessoas com deficiência, pelo fortalecimento das discussões sobre direitos humanos, proteção social, cidadania, em que este debate foi redirecionado para o entendimento e crítica do ordenamento político e jurídico vigente (Santos, 2011). Nesse sentido, a deficiência como consequência natural da lesão de um corpo (Diniz, 2007) passou a ser compreendida como "[...] uma das muitas formas de se habitar os corpos, podendo inclusive constituir objeto de orgulho pela diferença, como ocorre com as comunidades surdas" (Santos; Diniz; Pereira 2009, p. 16).

Esta transformação nos estudos sobre a pessoa com deficiência coincide com a inclusão das Ciências Humanas no debate. A deficiência passou a ser pensada não apenas como a expressão de uma lesão que impõe restrições à participação social e à cidadania, mas como resultado de uma estrutura social que oprime o corpo deficiente, em que a vivência desse corpo é constantemente marcada pelo estigma, desvantagem social e rejeição estética (Butler, 2003).

Com a entrada das Ciências Humanas no debate, os pressupostos biomédicos amparados na medicina, psicologia e na reabilitação dos corpos tornaram-se insuficientes para tratar a questão, e a discussão passou a ser vista por seus aspectos sociais, culturais, políticos e atitudinais. Segundo Santos, a “[...] deficiência não é mais um constructo da natureza e mero demarcador de identidade, mas, antes de tudo, uma relação social, histórica e política de poder que inscreve os corpos com variações em situações de desigualdade e opressão" (Santos, 2015, p. 263). De um corpo com anormalidade, a deficiência passou a ser concebida como um processo 
[...] que não se encerra no corpo, mas na produção social e cultural que define determinadas variações corporais como inferiores, incompletas ou passíveis de reparação/reabilitação quando situadas em relação à corponormatividade, isto é, aos padrões hegemônicos funcionais/corporais. Nesse sentido, a deficiência consiste no produto da relação entre um corpo com determinados impedimentos de natureza física, intelectual, mental ou sensorial e um ambiente incapaz de acolher as demandas arquitetônicas, informacionais, programáticas, comunicacionais e atitudinais que garantem condições igualitárias de inserção e participação social (Mello; Nuernberg, 2012, p. 636).

Nesta perspectiva, o modelo social da deficiência está de acordo com a "Convenção sobre os Direitos das Pessoas com Deficiência” e neste ponto de vista, por sua abrangência e polissemia, as categorias nativas em torno da experiência da deficiência foram finalmente incluídas (Mello; Nuernberg, 2012). Para tanto, o modelo social desafia os saberes biomédicos quando vê a deficiência não apenas pelo viés da corporificação de disfuncionalidade e sim como exteriorização de uma complexa relação entre corpo e sociedade permeada por opressões, exclusões, estigmas e, "nesse sentido, as experiências de opressão vivenciadas pelas pessoas com deficiência não estão na lesão corporal, mas na estrutura social incapaz de responder à diversidade, à variação corporal humana” (Mello; Nuernberg, 2012, p. 638).

Estas noções acabaram por influenciar programas governamentais como o BPC. Embora a concessão deste benefício tenha surgido em 1996, oito anos após a promulgação da Constituição Federal e três anos após a Lei Orgânica da Assistência Social (LOAS), foi apenas recentemente que sua legislação recebeu influência do modelo social da deficiência a partir de alguns marcos legais e acordos internacionais, a exemplo da publicação da Classificação Internacional de Funcionalidade, Incapacidade e Saúde (CIF) pela Organização Mundial de Saúde (OMS) em 2001 e da publicação da Convenção sobre os Direitos das Pessoas com Deficiência, aprovada pela Assembleia Geral das Nações Unidas (ONU) em 2006 (Santos, 2016).

Neste sentido, o Benefício de Prestação Continuada (BPC) é um programa assistencial de transferência incondicional de renda, equivalente a um salário mínimo, destinado à proteção de idosos e da pessoa com deficiência, de qualquer idade, com impedimentos de longo prazo, de natureza física, mental, intelectual ou sensorial, que comprovem não possuir meios para prover a própria manutenção nem de tê-la provida por sua família (Cartilha BPC, 2010). Resultante da pressão dos 
movimentos sociais de pessoas com deficiência durante o período da Constituinte, na década de 1980, o BPC é fruto de um momento no qual a assistência social se estruturava levando em consideração o combate à pobreza no Brasil (Medeiros; Barros; Neto, 2010). Nesse sentido, a Constituição Federal reconheceu deficiência e pobreza como temas que necessitam de intervenção do Estado, sendo o BPC um dos programas de transferência de renda que materializa as políticas de assistência social (Santos; Penalva, 2010).

Desde 1996, o BPC é concedido a pessoas com impedimentos corporais considerados como deficiências incapacitantes para o trabalho e a vida. A gestão, coordenação, regulação, financiamento, monitoramento e avaliação deste benefício é de responsabilidade do Ministério do Desenvolvimento Social e Agrário (MDSA) ${ }^{10}$ e ao INSS cabe sua operacionalização, incluindo o reconhecimento do direito e a concessão, com base nas avaliações médica e social (Vaistman; Lobato, 2017). Mesmo sendo um benefício da assistência social, o BPC é efetivado nas agências do INSS da Previdência Social, que têm a característica de gerenciar benefícios para os trabalhadores contribuintes do Regime Geral da Previdência Social (Medeiros; Barros; Neto, 2010).

Embora a concessão do BPC tenha iniciado em 1996, foi apenas recentemente que sua legislação recebeu influência do modelo social da deficiência. Por um lado, a CIF, ao ter substituído a Classificação Internacional de Doenças (CID), possibilitou qualificar a deficiência como uma experiência de segregação e opressão, resultado negativo da interação entre o corpo com lesão e a sociedade (Diniz, 2007). Por outro lado, a Convenção sobre os Direitos das Pessoas com Deficiência propiciou a compreensão da deficiência como parte da experiência humana, introduzindo o princípio do tratamento igualitário e provocando alterações nos marcos normativos dos países signatários (Santos, 2015; Dhanda, 2008). Contudo, como aponta Santos (2010a), as demandas defendidas pelo modelo social parecem ter tido pouca ressonância no estabelecimento de legislações que garantam os direitos da pessoa com deficiência no Brasil, percurso distinto de muitos países onde este modelo acabou por ter força normativa para influenciar o desenho de políticas públicas (Diniz et al., 2009).

O BPC foi uma das primeiras políticas que adotou na íntegra o conceito de pessoa com deficiência da Convenção de 2006 e, também, os parâmetros da CIF para avaliação das condições biopsicossociais da pessoa com deficiência. Caracteriza-se como uma política de assistência social e teve sua legislação modificada 
em 2007 (Santos, 2010b). Como destaca Wederson Santos (2015, p. 270) em outro texto,

a CIF permite avaliar as situações da deficiência, porque avalia a funcionalidade como aspectos positivos da interação entre um indivíduo (com determinada condição de saúde) e seus fatores contextuais (fatores ambientais e pessoais) (CIF, 2003). Dessa forma, quando a interação se dá de modo negativo, ocorrem as situações de deficiência. Isto é, a CIF chega às deficiências pela avaliação das consequências dos impedimentos (condições e estados de saúde), e não pelas causas deles.

Uma vez que o julgamento das condições sociais, de saúde e corporais da pessoa com deficiência passou a ser exigido no BPC, entrou em cena a avaliação social, como complementar à avaliação dos peritos médicos. Nesse sentido, o corpo com impedimento deixa de ser a medida solitária para definição da deficiência (Barbosa et al., 2010) e agora o grande desafio do BPC reside na relação entre os saberes biomédicos e sociais no processo pericial do INSS.

A inserção do modelo social da deficiência e da CIF foram de fundamental importância na ampliação do acesso ao BPC que, segundo Carneiro e Cavalcanti (2017), faz parte do Decreto 6.214/2007, que determinou tanto a implantação do novo modelo de avaliação quanto a avaliação do grau de deficiência, do grau de incapacidade para a vida independente e para o trabalho, a partir da avaliação social e médica, realizadas respectivamente pelo Serviço Social e pela Perícia Médica do INSS, a partir de junho de 2009. Essa avaliação da deficiência nas políticas de Assistência Social e Previdência tem exigido um esforço teórico-metodológico importante dos profissionais avaliadores:

no caso dos médicos peritos é o esforço de alcançar a relação entre o processo de saúde-deficiência e as manifestações verificáveis na dinâmica da vida do segurado ou do solicitante do BPC, utilizando as diretrizes e os conceitos da CIF. Para os assistentes sociais, o esforço está em utilizar-se dos instrumentos baseados na CIF como intermediações técnico-operativas para se alcançar a relação entre questão social e funcionalidade, para a devida caracterização da deficiência. Para a avaliação dos requerentes do BPC, foram elaborados instrumentos para a perícia médica e para os assistentes sociais que deveriam materializar tais premissas. Após formação de Grupos de Trabalho para elaborar o processo de avaliação, a perícia médica passou a avaliar os comprometimentos que existem nas Estruturas e Funções do Corpo, além da análise das restrições enfrentadas pelos requerentes do BPC no desempenho de suas Atividades e Participação na sociedade. Por sua vez, os assis- 
tentes sociais avaliariam os Fatores Ambientais e também itens específicos sobre as restrições nas Atividades e Participação (Santos, 2016, p. 3013-3012).

Outra mudança com a introdução da CIF, segundo alguns pesquisadores (Barbosa et al., 2010), é que esta mudou todo o padrão de apreciação do BPC, ampliando inclusive o número de concessões, pois a partir deste momento, as doenças crônicas incapacitantes entraram também no rol dos pressupostos de concessão deste benefício.

Em 2016, em decorrência da Emergência em Saúde Pública ocasionada pelo Zika vírus, surge nova alteração nas regras do BPC. Como informamos anteriormente, a Portaria $n^{\circ} 58$, de 3 de junho de 2016, concedeu prioridade às crianças com SCZ para o acesso a este benefício. Em Recife, esta prioridade começou a ser operacionalizada antes da publicação desta Portaria, segundo o relato da assistente Social do INSS:

A gente começou atender esses casos na agência, o serviço social em diálogo com os gestores. E aí a gente começou a identificar que estava se avolumando esses atendimentos e que a gente precisaria fazer uma prioridade nesses atendimentos. [...] A partir de uma prioridade, a gente dialogou com a perícia médica. Ainda não era uma questão nacional e acabou que o INSS estava saindo de uma greve e a gente precisava pagar esse período de greve com trabalho. A gente aqui na gerência Recife organizou um mutirão sobre o BPC. [...] Na verdade, a gente organizou dois. Então parte dos atendimentos de crianças com microcefalia a gente atendeu nesse mutirão, ainda antes dessa portaria, né? Ainda era o governo Dilma, ainda ia acontecer o impeachment... [...] Então, vira uma questão nacional e se avoluma ainda mais o número de atendimentos. Mas aí a gente já tinha essa sistemática de fazer uma prioridade quando chegava alguém na agência, antes dessa portaria dele (Michel Temer). Chegava alguém na agência, a gente tentava fazer os três atendimentos no mesmo dia ou então, a gente tentava fazer os dois atendimentos, o nosso e o da perícia médica. Porque, os três atendimentos, administrativo, avaliação social e avaliação médica, as vezes não era interessante, porque ocupava muito o tempo da família. ${ }^{11}$

O efeito principal desta Portaria para as famílias que têm filhos com SCZ, residiu, portanto, na prioridade e marcação mais acelerada da perícia médica e social, embora como demostramos acima, este fluxo em Recife, tenha sido adotado em momento anterior. A despeito desta Portaria constituir grande benefício para estas famílias, outras regras não foram flexibilizadas e diversas contradições do BPC persistem. 
Embora o BCP tenha adotado a CIF e o modelo social de deficiência e, para o caso específico das famílias que têm filhos com SCZ, a Portaria ${ }^{\circ} 58$ haja possibilitado o aumento das concessões, identificamos algumas contradições que geram consequências negativas para a abrangência do benefício e para as pessoas beneficiadas e suas famílias. Tais contradições foram, ao longo dos anos, debatidas por pesquisadores, pelas famílias e associações de pessoas com deficiência, mas foi em razão da epidemia de Zika vírus, resultando no nascimento de crianças com deficiência, que este debate ganhou força e novos contornos (Diniz, 2017) como veremos no item a seguir.

As contradições do benefício de prestação continuada e famílias atingidas pela síndrome congênita do Zika

Em Pernambuco, epicentro da epidemia de SCZ, as secretarias de assistência social (municipal e estadual) trabalharam de forma conjunta e articulada com as secretarias de saúde. Ao passo que as secretarias de saúde faziam buscas ativas para o fechamento dos casos notificados, as secretarias de assistência social buscavam estas famílias com o intuito de inseri-las nos benefícios sociais aos quais elas tinham direito (Bolsa Família e BPC).

Neste momento, entra em cena em Recife/PE, o Instituto Nacional de Seguro Social (INSS), que realizou ainda em março de 2016 o primeiro mutirão de acesso ao BPC. Na ocasião, como informamos anteriormente, o INSS de Recife começou a atender de forma prioritária estas famílias, trazendo ainda uma novidade: a possibilidade de realização das três fases da perícia (entrega de documentos, entrevista com a assistente social e a perícia médica) num único dia. Somente três meses depois do primeiro mutirão é que surge a Portaria $n^{\circ} 58$, de 3 de junho de 2016, efetivando a prioridade que já acontecia na prática em Pernambuco. Após esta experiência de mutirões prioritários em Pernambuco, outros Estados passaram a fazer o mesmo.

Contudo, em seu texto, esta Portaria não modificava as contradições históricas do BPC as quais as pessoas com deficiência vivenciavam. Por suas particularidades, uma síndrome ocasionada por negligência do Brasil em promover políticas efetivas de saneamento básico, acesso a água potável e controle do vetor da Zika (Aedes Aegypti), tanto as famílias atingidas pela SCZ quanto os pesquisadores de políticas públicas informavam que era preciso uma mudança substancial nas regras de acesso ao BPC. O discurso vendido de uma prioridade no BPC às famílias atingidas pela SCZ esbarrou nas contradições históricas deste benefício, como demonstraremos a seguir. 
A primeira contradição diz respeito ao fato deste benefício ter uma abrangência limitada, já que um dos critérios para sua concessão é que a renda familiar não ultrapasse 1 / 4 do salário mínimo por pessoa. O BPC é, portanto, o programa mais restritivo e com o mais baixo ponto de corte relacionado à renda, enquanto os demais programas de cunho assistencial apresentam, via de regra, um corte de 1/2 salário mínimo (Barbosa; Silva, 2003). O resultado é que inúmeras pessoas com deficiência se tornam inelegíveis em decorrência deste teto.

Uma segunda contradição, gerada ainda pelo ponto de corte de $1 / 4$ do salário mínimo, diz respeito a regra que determina a pessoa com deficiência como unidade alocadora do benefício e a família como unidade de comprovação da renda requerida. Esta regra "[...] coloca não só o beneficiário na 'armadilha da pobreza', mas toda a sua família, como condição de manutenção do benefício” (Barbosa, Silva; 2003, p. 229).

A terceira contradição diz respeito ao fato de que é vedado o acúmulo de salário-maternidade e BPC (Diniz, 2017) como demonstra Ana, mãe de Eduarda:

Ana: E eu estava precisando muito, aí eu falei: vou dar entrada no meu salário materno, aí eu peguei e dei entrada. Aí na hora da entrevista ela já disse que tinha sido aprovado, aí quando disse que foi aprovado, aí eles disseram que ia ser em março já a perícia (INSS/BPC). Quando eu fui fazer, fui passar na assistente social, fui fazer a perícia, ela disse que não ia dar certo o benefício dela, por causa desse salário materno, que ia chocar. Aí eu fui e falei com o gerente de lá, ele falou que eu podia tirar, eu já tava com a carta e com a data para tirar o meu salário materno, aí eu disse: não, se vai prejudicar pode cancelar o salário materno, eu tiro só o dela. Aí o gerente disse: não, pode tirar o seu salário materno, se der errado pode vir falar comigo, aí eu tirei e fiz a perícia, quando eu fui pegar o resultado deu negado. Veio negado, veio como se eu tivesse uma renda... ${ }^{12}$

Ana ainda nos informou que foi orientada a judicializar para ter acesso ao BPC, mas que ficou com receio da demora da justiça. A outra saída oferecida foi entrar com um recurso no INSS pedindo nova apreciação. O recurso foi aceito e Ana conseguiu, depois de muita burocracia, receber o salário-maternidade e o BPC. Contudo, como demostraremos a seguir o itinerário de Ana pela malha burocrática do INSS e BPC não tinha acabado, surgindo assim uma quarta contradição. O fato é que o valor recebido pelo Bolsa Família ou pelo BPC tem sido considerado para o cálculo de acesso a estes benefícios, o que acaba por ultrapassar o corte de 1 / 4 do 
salário mínimo. O que ocorre é que muitas famílias que tinham o BPC, acabaram por perder o Bolsa Família sob o argumento de excesso de renda, como indica Ana, mãe de Eduarda, na mesma entrevista mencionada acima:

Silvana Matos: Você recebe Bolsa Família?

Ana: Cortaram...

Silvana Matos: Você tinha o Bolsa Família antes?

Ana: Na verdade, quando eu fui com os papéis para a assistente social preencher o BPC dela, eles perguntaram se eu tinha o bolsa família, aí eu disse não, e que tentava há cinco anos mas nunca consegui. Aí ela: “ah, não, vamos ajeitar”, aí colocou Eduarda e ajeitou. Eu fui, no início de fevereiro, elas mandaram eu procurar no final de março, porque o final era zero do meu cartão. Disse no final de fevereiro, podiam procurar no dia 29 que já ia tá no meu dinheiro, pois eu liguei e eles disseram que tinha liberado, só que faltava a folha lá de pagamento que não tinha sido liberada ainda, não ia tirar aquele mês, aí marcou para março. Quando eu fui, eu tirei o mês de março e fevereiro, eu recebia 329,00. Aí, quando foi o ano passado, eu cadastrei o BPC no bolsa família, aí diminuiu para 163,00, aí só ficou vindo mensagem para eu comparecer, eu não compareci. Aí foi e cortou.

Neste sentido, é que pesquisadores (Diniz, 2017; Penalva; Diniz; Medeiros, 2010) têm argumentado que é preciso garantir a aplicação dos entendimentos da justiça de que o valor do Bolsa Família não pode integrar o cálculo de renda mensal para concessão do BPC e vice-versa, já que cada benefício cumpre seu papel distinto no amparo social. Enquanto o BPC é uma renda garantida para o custeio das demandas da pessoa com deficiência, o Bolsa Família deve assegurar o custeio dos demais membros que pararam de trabalhar e diante disto tiveram sua condição de vulnerabilidade agudizada. Como o cuidado com a pessoa com deficiência recai mais sobre a mulher (Fleischer, 2017; Carneiro; Fleischer, 2018; Alves; Fleischer, 2018; Matos; Lira; Meira, 2018), muitas tiveram que parar de exercer o trabalho remunerado. Esse afastamento do mundo do trabalho acabou por representar um gasto indireto da epidemia, havendo uma queda no rendimento concomitantemente ao aumento das despesas.

A quinta contradição, analisada em artigos anteriores (Silva; Matos; Quadros, 2017; Scott et al., 2018) e constantemente enfocada pelas mães que têm filhos com deficiência, e em especial, pelas que têm filhos com SCZ, é a proibição de vínculo empregatício com carteira assinada e da contribuição das mães cuidadoras ao INSS 
como donas de casa. A consequência é que estas mulheres precisam se afastar de trabalhos com carteira assinada e não podem contribuir para o INSS como donas de casa, o que termina por impossibilitá-las da obtenção do direito a aposentadoria por tempo de contribuição, como demonstra esta mãe:

Eu tenho BPC do meu filho, que é a única renda que eu tenho hoje, já que eu deixei de trabalhar pra me dedicar integralmente, 24 horas, ao emprego de mãe. Com isso eu não posso pagar nem meu INSS nem como dona de casa, sabia? Aquela taxa de 28 reais, eu não posso pagar, porque eu tenho BPC. Vai cortar meu BPC, o INSS diz. Então assim, sabe o que é que vai acontecer? Eu desejo vida longa ao meu filho, mas se daqui a 15, 20 anos ele vir a falecer, eu não vou poder mais me aposentar. Quem é que vai querer empregar uma mulher de 45, 50 anos? E essa mãe vai viver como? (Relato de uma mãe que tem filho com a SCZ, em 24 de maio de 2017, na Frente Parlamentar em Defesa da Pessoa com Deficiência, Assembleia Legislativa de Pernambuco).

A sexta contradição também está ligada ao critério relacionado à renda familiar e sua influência na relação entre deficiência, BPC e dinâmicas das relações familiares que acabam sofrendo remodelação. É muito frequente a atribuição do "abandono" pelo parceiro ser provocada pela sua indisposição de incrementar dedicação nos cuidados da criança com deficiência (Scott et al., 2018). Nesta intricada relação entre deficiência, BPC e remodelação das relações familiares, uma advogada que atende crianças com doenças raras, SCZ e doenças neuromusculares informou que

[...] geralmente os pais somem, e aí essa mãe não sabe nem onde é que está esse pai. Elas ficam completamente desassistidas. Então muitas vezes é assim: ... uma é que não contam com o pai... outras, são aquelas que têm o pai, mas já conseguiram o BPC. Então não querem pedir a pensão, porque se pedir a pensão perde o benefício, aí elas não querem. Muitas vezes a gente faz "poxa, mas você não sabe onde é que tá o pai? Ele tem carteira assinada?" "Tem!" "Então vamos entrar com a ação, para a gente pedir a pensão!" "Mas doutora, ele recebe um salário mínimo, aí se juntar vai passar do teto lá do INSS e eu vou perder o benefício". Aí elas não entram, não pedem nada, não pedem visitação, não pedem nada, preferem ficar sozinhas, então tem isso que conta. ${ }^{13}$

O ponto de corte de $1 / 4$ do salário mínimo, no BPC, portanto, acaba incidindo de forma colateral nas dinâmicas familiares, na responsabilidade paterna, no tocante 
às questões econômica, afetiva e de cuidado. Por outro lado, as mães que continuam casadas e cujos maridos possuem renda fixa, mas que tiveram que deixar de trabalhar em decorrência da rotina de cuidados com seus filhos, ficam desamparadas com relação ao BPC, já que a renda diminui, mas não o bastante para as tornarem elegíveis ao benefício, e os gastos aumentam com incremento de remédios, suplementos alimentares e intensificação do itinerário terapêutico dos filhos. No caso de Flávia, mãe de Jorge, que tem SCZ, negar o marido (e sua renda) para o receber o BPC está fora de cogitação. Segundo ela,

eu não minto, eu não nego meu esposo, não nego que eu sou casada. E eu acho assim, é por isso que eu estou aqui hoje, é pra brigar por um dinheiro de direito do meu filho, que não tem ameaça dele perder, porque o pior eles já fizeram com meu filho. Meu filho tem uma coceira e não sabe chegar com a mão para coçar, meu filho se morde, me morde, porque ele não tem coordenação. $O$ pior que eles podiam fazer pelo meu filho, eles fizeram. O dinheiro que eu quero, não é pra eu luxar, é só pra dar uma condição mais digna pra ele $[\ldots] .^{14}$

Flávia, mãe de Jorge, até hoje não conseguiu ter acesso ao BPC para seu filho. Segundo ela, não houve nem a perícia médica, nem a avaliação social, já que, na primeira etapa, que é administrativa e de análise de documentação, ela foi cortada porque ultrapassou o critério de do salário mínimo de renda familiar. Sobre esta questão, Flávia relata:

Nunca consegui por causa da renda dele (marido). Eu comprei um apartamento pra mim financiado em 2011, eu trabalhava, era outra realidade, eles querem viver da minha realidade passada. Eles têm que tá preparado para entender o que é o nosso presente. $\mathrm{O}$ apartamento quando eu financiei, eu trabalhava, eu gerenciava uma loja, eu tinha renda, não quer dizer o que apartamento hoje é meu não, eu comprei ele apostando que eu sempre ia trabalhar.

Recentemente, em decorrência do cenário político brasileiro, o BPC tem incorporado novas regras e se tornado ainda mais restritivo. Estas mudanças estão descritas no Decreto n 8.805 de 07 de julho de 2016. Duas alterações merecem destaque. A primeira torna obrigatória a inclusão dos beneficiários e seu grupo familiar no Cadastro Único (CadÚnico) como condição para concessão e manutenção do benefício. Sobre esta alteração, uma assistente social do INSS em Recife, relatou o seguinte: 
Eu não tenho uma análise profunda como é para as outras políticas, mas para o BPC a gente tem uma crítica, porque tanto o grupo familiar é diferente, como ele coloca um contexto para um benefício que já tem um corte muito baixo, de $1 / 4$ de salário mínimo e isso acaba prejudicando o acesso das pessoas. Porque, por exemplo, o Cadúnico leva em consideração a questão da ajuda, a ajuda é contabilizada, mesmo se não for uma ajuda regular, ela é contabilizada como uma renda. E aí, eu não tenho um estudo, mas assim, de forma empírica, a gente sabe que isso vem prejudicando as pessoas. [...] Então, existe uma distorção aí, que vem prejudicando e isso, a gente tem sentido que esse processo deu uma afunilada, a gente sentiu esse impacto no número de avaliações nossas, isso teve um impacto grande, os números de avaliações vêm diminuindo. ${ }^{15}$

A segunda alteração, no Art. $15 \S 5^{\circ}$ do mesmo decreto, informa que "na hipótese de ser verificado que a renda familiar mensal per capita não atende aos requisitos de concessão do benefício, o pedido deverá ser indeferido pelo INSS, sendo desnecessária a avaliação da deficiência”. O impacto desta mudança foi assim analisado pela mesma Assistente Social do INSS em Recife:

Além da questão CadÚnico, antes as pessoas que tinham a renda superior ou igual a 1/4, mesmo identificando isso no momento do requerimento, elas passavam pela avaliação social e pela avaliação médica, porque na avaliação médica, isso ampliava o acesso delas aos direitos em si, porque mesmo tendo 1 / 4 de um salário mínimo negado, quando ela passava pela avaliação médica, pela avaliação social e médica, se foi caracterizado a questão dos impedimentos funcionais dela, do comprometimento funcional dela [...]. Agora não passa mais pela avaliação social e médica. Algumas pessoas, antes de judicializar, elas ainda tentavam na própria junta de recursos do INSS, então elas tinham pelo menos a avaliação médica dos impedimentos funcionais dela.

Estas mudanças acarretaram diversas distorções e impactos na concessão do BPC, que acabaram por incidir na vida das famílias atingidas pela SCZ. Flávia não teve sequer o direito que seu filho fosse avaliado pela perícia médica e social no INSS devido às novas regras do Decreto.

Em decorrência de inúmeros cerceamentos de direitos, incluindo a não concessão do BPC, algumas mães que têm filhos com SCZ, têm ampliado seu itinerário de cuidado, para o judiciário, através de ações nas defensorias públicas da União e dos Estados. Esta foi a saída que Flávia encontrou. Contudo o judiciário negou seu 
recurso baseado na perícia da Assistente Social ${ }^{16}$. No acórdão desta decisão consta o parecer social produzido pela Assistente Social que traz as circunstâncias socioeconômicas da família de Flávia que diz que o

autor [Jorge, filho de Flávia] mora com os pais em um apartamento dentro de um condomínio fechado com estrutura de alvenaria, com boas condições de moradia. Possui paredes rebocadas e pintadas em necessidades de reparos, piso de cerâmica, com forro. O apartamento é localizado no segundo andar de um total de quatro andares, com acesso apenas de escada. Possui mobília usada em bom estado de conservação, necessária para o cotidiano com eletrodomésticos para uma casa completa. Com boa higienização e boa ventilação. Possui um total de cinco cômodos pequenos, distribuídos da seguinte forma: sala, dois quartos, cozinha e banheiro (Neto, 2018, p. 2).

O ponto de vista de Flávia sobre a perícia da Assistente Social é outro:

Quando judicializei foi uma Assistente Social lá na minha casa, mas o que é que acontece? Ela olha meu condominiozinho, apesar de eu não ter muito móvel, porque eu me mudei, mas tem cerâmica, tem eletrodomésticos, porque na minha vida eu sempre planejei tudo. Só que não tava nos nossos planos ser vítima de um descaso tão cruel, entendeu? Aí quer dizer, desestruturou tudo. E aí mais uma vez me negaram o BPC [...] ] que conta é que meu marido trabalha, só que eles (INSS) não entendem que meu marido trabalha de venda, ele é muito esforçado, então ele atinge a meta que ele atinge. Só que antes ele já ganhava esse dinheiro, mas tinha a minha renda também. Hoje só tem a dele. Eles querem que eu chegue no estado de miserabilidade, entendeu?

Neste sentido, após as referências de diversos discursos em torno do acesso ao BPC, seja da perícia médica ou avaliação social do INSS, das Assistentes Sociais, do judiciário e das famílias atingidas pela $\mathrm{SCZ}$, questionamos: que pessoa com deficiência merece proteção pelo Estado? Quais são os valores e condições maiores para que a pessoa com deficiência e com SCZ tenha seus direitos assegurados via BPC? A deficiência ou a pobreza? Os diversos relatos das famílias com filhos com SCZ, as leis e Portarias apontam que a deficiência tem sido relativizada em detrimento do critério da pobreza, e que este processo ainda está em marcha em decorrência da situação política do Brasil e do incremento de novos decretos.

Para o caso da SCZ, a portaria que buscou dar a "prioridade da prioridade", 
embora tenha resultado na velocidade do acesso ao BPC, não versava sobre questões importantes apontadas pelas famílias como exemplifica Flávia, mãe de Jorge:

[...] eles querem que a gente se enquadre nas normas do BPC. Só que não é realidade das famílias que foram atingidas pelo Zika, eles têm que buscar uma forma de quê? De estudar o que eles causaram de impactos nessas famílias. O que foi, no caso da minha: a minha renda caiu, a minha qualidade de vida financeira completamente mudou, a minha questão como, como é que a gente chama das mulheres que buscam muito hoje, que eu tinha e hoje eu sinto que perdi, que é a minha autonomia, até vaidade. Já me peguei muitas vezes chorando, porque eu vivo com o cabelo dado nó, ou que as pessoas me cobram porque eu engordei muito, mas tudo é reflexo da minha ansiedade. Eu praticava esporte à noite, eu fazia caminhada, hoje eu não tenho mais coragem, porque eu tô tão exausta. Eu passo quase o dia todo com meu filho no meu colo. [...] Quer dizer, eles têm que entender que as contas não param de chegar, e eu parei de trabalhar, fui interrompida, por imprudência deles também quando deixaram de fazer um saneamento, quando deixaram de tomar medidas preventivas eficazes contra o vetor, quando eles falharam na informação...

E são justamente essas famílias e mais especificamente essas mulheres, que demonstram as lógicas excludentes e contraditórias das políticas assistenciais e mais especificamente do BPC. Para elas, o Estado não assumiu a responsabilidade pela guinada em seus cursos de vida e pela precariedade, pauperização e vulnerabilidade em que foram jogadas com a epidemia do Zika. Flávia teve sua trajetória completamente modificada pela negligência do Estado, e quando solicitou reparação via INSS, teve o acesso ao BPC negado. Mais uma vez, Flávia tentou o acesso ao BPC via judicialização, e novamente o benefício foi negado, com a chancela da assistente social em visita domiciliar, que argumentou que ela não era suficiente pobre para ter acesso ao benefício, embora seu filho fosse uma pessoa com deficiência. A ruptura biográfica (econômica e social), o percurso de vida modificado pela epidemia acabam por não serem critérios adotados para concessão; e Flávia enfatiza, com muita propriedade, que as políticas assistenciais só levam em conta uma realidade socioeconômica que não existe mais.

Ana, mãe de Eduarda, por sua vez caiu na malha contraditória de acesso ao BPC por três vezes. Foi informada pelo próprio INSS que poderia ter acesso ao salário-maternidade e por causa disso, seu BPC foi negado. Recorreu, conseguindo acesso 
aos dois benefícios, mas foi informada que poderia ter o Bolsa Família; e requerendo este benefício, teve seu BPC cortado.

Por outro lado, ter garantido o BPC não afasta as inseguranças e as angústias destas mães (Silva; Matos; Quadros, 2017), uma vez que estas não podem exercer trabalhos com carteira assinada nem contribuir para o INSS como donas de casa. A única renda que elas possuem é o benefício que está no nome do filho e que cessará caso esta criança venha a óbito.

Assim, a questão sobre um tratamento diferenciado de ingresso no BPC tem sido constantemente debatida pelas famílias que têm filhos com SCZ. Para estas famílias, é preciso que seja levado em consideração que a ocorrência da deficiência de seus filhos é resultado da negligência do Brasil em promover o saneamento básico, o acesso a água potável e o controle do vetor da Zika (Aedes Aegypti). Se por um lado a "prioridade da prioridade" teve papel prático no Estado do Pernambuco com a implantação de uma Área Técnica de Vigilância em Zika, na criação do Núcleo de Apoio às Famílias de Crianças com Microcefalia (NAFCM) e na prioridade de atendimento das crianças com SCZ na Central de Regulação do Estado, por outro, em se tratando das políticas nacionais, a exemplo do BPC, esta "prioridade da prioridade”, não foi efetivada, já que, o único critério modificado foi o acesso mais rápido a perícia no INSS.

Nesse sentido, as contradições históricas do BPC foram mantidas e ampliadas ainda mais com a chegada da SCZ, já que o argumento das famílias e de diversos pesquisadores é que a ocorrência da SCZ é resultado da negligência do Brasil, além da falha em discutir sobre transmissão sexual do vírus Zika, direitos reprodutivos e aborto.

A “prioridade da prioridade" com relação ao BPC tem sido um exemplo de como a ideia de executar ações emergenciais para driblar os entraves do acesso à assistência para um grupo específico não garante prontamente a sua inclusão plena nem o atendimento de suas especificidades. Pode, sim, criar novas divisões e conflitos que precisam ser seriamente considerados.

As contradições e alterações do BPC apontadas acima contribuem para dificultar o acesso ao benefício. São muitos os condicionantes e requisitos que afunilam o atendimento de todos os critérios estipulados, no tocante a pessoas com deficiência e crianças com SCZ, acabando por excluir muitos dos que precisam deste apoio para sobreviver com menor precariedade. As especificidades dessas pessoas precisam ser consideradas para que o modelo social da deficiência e a incorporação do 
CIF não sejam palavras escritas que não ressoam efetivamente na prática.

Mas, as famílias afetadas pela SCZ não têm assistido a estes acontecimentos de forma passiva. Tem crescido entre estas a organização política através das associações (Scott et al., 2017, 2018; Matos, 2018). Existem atualmente diversas associações com foco na SCZ em todo o Brasil, e em julho de 2017 foi criada a Frente Nacional por Direitos das Pessoas com a Síndrome Congênita do Zika Vírus (FNLDPSCZ). Estas associações e a FNDPSCZ têm lutado ultimamente por políticas públicas voltadas não somente para as crianças com SCZ, mas também para seus cuidadores.

Em 28 de março de 2018, a pesquisa Etnografando Cuidados esteve presente, junto com a FNDPSCZ, numa reunião com o então Ministro do Desenvolvimento Social (MDS), Osmar Terra, e com seu Secretário Executivo, Alberto Beltrame, em Brasília. Entre as diversas pautas debatidas, estava o BPC e suas incompatibilidades com os desafios travados pelas famílias atingidas pela SCZ. Uma das possibilidades aventadas nesta reunião foi a transformação do BPC num benefício indenizatório, como foi feito com as vítimas da Talidomida, na década de 1960, do Césio 137 em Goiânia, e da Hemodiálise em Caruaru. Desta forma, o corte de 1/4 do salário mínimo perderia seu efeito.

Em consequência dessas primeiras reuniões com o MDS, em 05 de setembro de 2019, o presidente Jair Bolsonaro sancionou a Medida Provisória 894/2019 que “institui pensão especial destinada a crianças com microcefalia decorrente do Zika Vírus, nascidas entre 1o de janeiro de 2015 e 31 de dezembro de 2018, beneficiárias do Benefício de Prestação Continuada." ${ }^{17}$ Após a publicação desta Medida Provisória a Frente Nacional por Direitos das Pessoas com a Síndrome Congênita do Zika Vírus (FNLDPSCZ) lançou uma nota oficial com sete pontos que deveriam ser melhorados na MP. ${ }^{18}$ Dentre eles está o pedido para que a pensão s não seja atrelada ao fato da criança já ser beneficiária do BPC.

Em decorrência da publicação da MP 894/2019, houve uma nova rodada de negociações e a FNLDPSCZ se reuniu novamente com o ministro Osmar Terra em 20 de setembro de 2019 e com diversos deputados e senadores ${ }^{19}$ que compõem a Comissão Mista da MP com o intuito de sensibilizar para que a MP seja mais inclusiva e atenta as demandas das famílias atingidas pela Síndrome Congênita do Zika. Um plano de trabalho foi aprovado pela Comissão Mista e audiência públicas com as famílias, pesquisadores e o Estado foram requisitadas. A perspectiva da Comissão Mista é votar esta Medida Provisória até novembro de 2019. 


\section{Considerações finais}

Embora a implantação do modelo social de deficiência e avaliação social no INSS tenham ampliado o número de beneficiários do BPC, problemas estruturais persistem e afastam o ingresso de muitas pessoas com deficiência do amparo assistencial, incluindo as crianças com SCZ. Esta "prioridade da prioridade" para as crianças com SCZ, gerada em decorrência de Emergência de Saúde Pública gerou novos contornos na discussão sobre a pessoa com deficiência. Se por lado essa prioridade (mesmo com sua pouca efetividade para o acesso ao BPC) é criticada por alguns gestores da saúde e por parcelas das pessoas com deficiência, por outro lado as famílias e associações atingidas pela SCZ relatam que é preciso uma discussão sobre a especificidade de seu caso. Uma outra crítica à "prioridade da prioridade”, fruto da situação "extraordinária”, contornada pelos efeitos de uma Emergência em Saúde Pública, é que ela não é sustentável. Criaram-se novos fluxos de atendimento sem que houvesse efetiva melhoria nas ações ordinárias: atenção básica, especializada e ingresso no BCP.

Neste sentido, nosso argumento de que embora o Estado venda a ideia de uma “prioridade da prioridade” no acesso ao BPC para as famílias atingidas pelo SCZ, esta ideia não é efetivada quando observamos as contradições e impedimentos no seu acesso. O efeito principal desta prioridade reside apenas na implementação de uma Portaria que versou sobre a marcação mais acelerada da perícia médica e social no INSS, embora este fluxo tenha sido adotado em momento anterior, em Recife.

Não há, por assim dizer, mudanças significativas nas regras de acesso ao BPC com a chegada da SCZ, e questões contraditórias permanecem, como: (1) o corte de 1 / 4 do salário mínimo para o acesso ao benefício; (2) a pessoa com deficiência como unidade alocadora do benefício e a sua família como unidade alocadora de recursos, levando não só o beneficiário mas como toda a sua família a "armadilha da pobreza” como condição de manutenção do benefício”; (3) o impedimento no acúmulo de BPC, Bolsa Família e licença-maternidade; (4) a proibição de vínculo empregatício com carteira assinada e da contribuição das mães cuidadoras ao INSS como donas de casa.

Pelo contrário, com o surgimento da SCZ, o BPC tornou-se ainda mais contraditório, como bem exemplifica Flávia, mãe de Jorge, que atribui a condição de seu filho, e como ela muitos pesquisadores também, à negligência do Estado Brasileiro. Estas famílias tiveram que se sujeitar às mesmas regras preestabelecidas pelo BPC, sem que fosse levado em consideração o fato de que a epidemia modificou seus cursos de vida e incidiu fortemente na precarização, pauperização e vulnerabilidade 
das mesmas. Nesse sentido, as políticas assistenciais, e mais especificamente o BPC, têm levado em consideração, para concessão do benefício, uma realidade socioeconômica que não atende a realidade das famílias.

O BPC, como demonstramos ao longo deste artigo, é permeado de muitas contradições relacionadas aos critérios de elegibilidade que contemplam pouco a realidade vivida pelas famílias que têm filhos com SCZ. Apesar de ter fortalecido uma luta antiga relacionada aos diretos de pessoas com deficiência, tem dividido opiniões quanto ao tratamento específico que recebe, evidenciando nosso argumento de que a deficiência tem sido relativizada em detrimento do critério da pobreza, como demonstram os teóricos e as falas das mulheres.

E ainda, o BCP poderia ser um auxílio na diminuição das desigualdades de gênero dentro das famílias de crianças com SCZ ou de pessoas com deficiência, especialmente aquelas decorrentes das práticas de cuidado. No que se refere a SCZ, a maior parte das cuidadoras são as mães que deixam seus empregos para poder dar assistência à criança com SCZ, enfrentando a falta de dinheiro, a sobrecarga do trabalho de cuidado e, muitas vezes, o abandono do marido. O BPC poderia ser um aliado, na medida em que auxiliasse na manutenção da condição financeira que as famílias ou as mães chefes de família possuíam antes da chegada do bebê com SCZ.

Recebido: 07/03/2019

Aprovado: 29/07/2019

Silvana Sobreira Matos é Doutora em Antropologia pelo PPGA/UFPE com estágio sanduíche PNPD/CAPES na Università Degli Studi Roma Tre (2014). Mestre em Sociologia: Teoria, Metodologia e Ricerca na Università Degli Studi Roma Tre (2012). Mestre em Antropologia - PPGA/UFPE (2008). Graduada em Ciências Sociais/UFCG (2005), Graduanda em Comunicação/ UEPB (2003). Desenvolveu pesquisa de pós-doutorado (bolsista da CAPES, 2016) no projeto "A Geopolítica Acadêmica da Antropologia da Religião no Brasil” (PPGA/UFPE) coordenado por Roberta Bivar C. Campos. Pesquisadora do Observatório de Cultura, 
Religiosidades e Emoções - OCRE/UFPE e do Núcleo de Família, Gênero e Sexualidade (FAGES/UFPE). Atualmente realiza pesquisa de Pós-doutorado no projeto Etnografando Cuidados“Etnografando Cuidados”. ORCID: 0000-0002-6515-7506 Contato: silvanasmatos@gmail.com

Marion Teodósio de Quadros é Professora Associada do Departamento de Antropologia e Museologia e integrante permanente do Programa de Pós-Graduação em Antropologia da Universidade Federal de Pernambuco (UFPE), Recife - PE, Brasil. Concluiu o Bacharelado (1990) e a Licenciatura (1992) em Ciências Sociais, Mestrado em Antropologia (1996), Doutorado em Sociologia (2004) e Pós-Doutorado (tema: Gênero, sexualidade e saúde) no Programa de Pós-Graduação em Antropologia (2005-2006), todos na UFPE. Possui Pós-Doutorado (tema: Antropologia, gênero e desenvolvimento) no Center for Latin American Studies da University of Florida (2012-2013). Participa do Laboratorio Iberoamericano para el Estudio de las Sexualidades (Red LIESS) reconhecido pela Asociación Universitaria Iberoamericana de Postgrado (AUIP), Espanha. Integra o FAGES (Núcleo de pesquisa em Família, Gênero e Sexualidade) da UFPE como pesquisadora e coordena o GEAD (Grupo de Pesquisa em Educação, Alteridades e Desigualdades) da UFPE. Tem experiência na área de Antropologia, com ênfase nos seguintes temas: gênero, sexualidade, feminismo, saúde, saúde reprodutiva, educação, família. ORCID: 0000-0002-1123-0923 Contato: marionteodosio@yahoo.com

Ana Cláudia Rodrigues da Silva é professora adjunta do Departamento de Antropologia e Museologia e integrante permanente do Programa de Pós-Graduação em Antropologia da Universidade Federal de Pernambuco (UFPE), Recife - PE, Brasil. Foi bolsista PNPD no Programa de Pós-graduação em Saúde Coletiva da UFPE (2013-2014). Possui doutorado em Antropologia pela UFPE (2013) integra o FAGES (Núcleo de pesquisa em Família, Gênero e Sexualidade) da UFPE. Atualmente desenvolve pesquisa no projeto Etnografando Cuidados"Etnografando Cuidados e Pensando Políticas de Saúde e Gestão de Serviços para Mulheres e Seus Filhos com Distúrbios Neurológicos Relacionados com Zika em Pernambuco, Brasil "( MCTIC/FNDCT - CNPq / MEC-CAPES/MS-Decit No 14/2016) com foco em políticas públicas de saúde e antropologia da ciência. ORCID: 0000-0002-09653193 Contato: acrodriguess@gmail.com 


\section{Notas}

1. Uma versão anterior deste artigo foi apresentada no OP 02. Anthropology of Abnormalities no 18th IUAES World Congress: World (of) Encounters: The Past, Present and Future of Anthropological Knowledge, July 16-20, 2018 e publicada nos anais do evento sob o título: A construção da deficiência em Síndrome Congênita do Zika Vírus: o discurso das famílias afetadas e do Estado.

2. A pesquisa Etnografando Cuidados e Pensando Políticas de Saúde e Gestão de Serviços para Mulheres e Seus Filhos com Distúrbios Neurológicos Relacionados com Zika em Pernambuco, Brasil, sob a coordenação de Russell Parry Scott da FAGES (Núcleo de Família, Gênero, Sexualidade e Saúde) da Universidade Federal de Pernambuco, tem o apoio de CAPES (8888.130742/201601), CNPq (440411/2016-5), Decit/SCTIE/MS, e, sob o título Action Ethnography on Care, Disability and Health Policy and Administration of Public Service for Women and Caretakers of Zika vírus affected Children in Pernambuco, Brazil, tem o apoio de FACEPE/Newton Fund (APQ 0553-7.03/16). Este artigo também fez parte das atividades de estagio pós-doutoral da coautora Marion Teodósio de Quadros, por meio da Bolsa PDE CNPq, processo n. 204337/2018-6.

3. A Frente Nacional na luta pelos direitos da pessoa com a Síndrome Congênita do Zika foi criada em 12 de julho de 2017 e reúne diversas associações de SCZ de todo o Brasil com o intuito de discutir os rumos das políticas de saúde e assistência voltadas para essas famílias. A Frente não tem sede própria e as discussões são realizadas virtualmente através do aplicativo de mensagens WhatsApp. Esse grupo de WhatsApp, para além de servir como um fórum de discussão sobre tratamentos, terapias e especificidades de cada Estado e associação, é também importante plataforma de sociabilidade na qual as famílias podem conversar sobre o cotidiano, ganhos e evoluções de seus filhos e também se confortar em casos de internações e óbitos.

4. Entrevista realizada por Silvana Matos com Enrique Vazquez, no dia 20 de junho de 2018, para a pesquisa Etnografando Cuidados.

5.Este artigo é fruto de nossas discussões no OP 02. Anthropology of Abnormalities no 18th IUAES World Congress: World (of) Encounters: The Past, Present and Future of Anthropological Knowledge July 16-20, 2018, que buscou questionar o lugar e os sentidos da ideia de anormalidade nas subjetividades e nas corporalidades, observando as interfaces em que a noção é criada, deslocada e subvertida.

6. Os nomes das entrevistadas e de seus filhos foram trocados para assegurar o anonimato.

7. Entrevista realizada por Silvana Matos e Luciana Lira com Marta, mãe de Carlos, em 18 de maio de 2017, para a pesquisa Etnografando Cuidados.

8. Entrevista realizada por Silvana Matos com uma gestora em 13 de junho de 2018, para a pesquisa Etnografando Cuidados.

9. Entrevista realizada por Silvana Matos, Luciana Lira, Marion Quadros e Russel Parry Scott com Laura Patriota, em 19 de dezembro de 2017, para a pesquisa Etnografando Cuidados.

10. Com as mudanças no executivo nacional ao longo dos anos, o MDSA teve sua sigla e composição alteradas. Atualmente, no governo Bolsonaro, o MDSA se tornou Ministério da Cidadania, responsável ainda pelo BPC, e inclui ainda os Ministérios da Cultura e Esporte.

11. Entrevista realizada por Silvana Matos com a Assistente Social do INSS em Recife, no dia 26 de junho de 2018, para a pesquisa Etnografando Cuidados. 
12. Entrevista realizada por Silvana Matos com Ana, mãe de Eduarda, em 22 de agosto de 2018, para a pesquisa Etnografando Cuidados.

13. Entrevista realizada por Silvana Matos e Ícaro Costa, com a advogada das associações, no dia 10 de julho de 2017, para a pesquisa Etnografando Cuidados.

14. Entrevista realizada por Silvana Matos, com Flávia, mãe de Jorge, no dia 28 de março de 2018 , para a pesquisa Etnografando Cuidados.

15. Entrevista realizada por Silvana Matos com a Assistente Social do INSS em Recife, no dia 26 de junho de 2018, para a pesquisa Etnografando Cuidados.

16. Quando ocorre o indeferimento da solicitação do Benefício de Prestação Continuada (BPC) administrativamente no Instituto Nacional de Seguridade Social (INSS), o usuário tem direito a recorrer ao Juizado e solicitar recurso. Desta forma, quando o processo é instaurado, os Assistentes Sociais peritos inscritos no Juizado desenvolverão a Perícia Social, que terá como resultado o Laudo Social, que será apresentado ao Juiz e juntado aos autos processuais (Souza; Vitorino; Giaqueto, 2016).

17.Consultar https: / / legis.senado.leg.br/sdleg-getter/documento?dm=8004249\&t-

$\mathrm{s}=1570126290705 \&$ disposition=inline Acesso em: 04 de outubro de 2019.

18.Consultar https: / /www.facebook.com/filhosdebencao/pho-

tos/a.517113708639239/940950499588889/?type=3\&theater Acesso em: 04 de outubro de 2019.

19. A pesquisadora Silvana Matos participou entre os dias 20/09/19 e 24/09/19 em Brasília/DF de algumas dessas reuniões da Frente com os deputados e senadores.

\section{Referências}

ALVES, Paulo César. 2015. Itinerário terapêutico e os nexus de significados da doença. Revista de Ciências Sociais, v. 42, n. 20, p. 29-43.

ALVES, Raquel Lustosa C.; FLEISCHER, Soraya. 2018. "O que adianta conhecer muita gente e no fim das contas estar sempre só?” Desafios da maternidade em tempos de Síndrome Congênita do ZikaVírus. Revista Anthropológicas, ano 22, v. 29, n. 2, p. 6-27.

BARBOSA, Lívia; DINIZ, Debora; SANTOS, Wederson. 2010. Diversidade corporal e perícia médica no Benefício de Prestação Continuada. In: DINIZ, Debora, MEDEIROS, Marcelo; BARBOSA, Lívia (orgs.). Deficiência e igualdade. Brasília: LetrasLivres; Editora Universidade de Brasília, p. 131150.

BARBOSA, Maria Madalena Martins; SILVA, Maria Ozanira da Silva e. 2003. O Benefício de Prestação Continuada - BPC: desvendando suas contradições e significados. Ser social, n. 12, p. 221-224.

BUENO, Flávia Thedim Costa. 2017. Vigilância e resposta em saúde no plano regional: um estudo preliminar do caso da febre do Zika vírus. Ciência \& Saúde Coletiva, v. 22, n. 7, p. 2305-2314.

BUTLER, Judith. 2003. Problemas de gênero: feminismo e subversão da identidade. Rio de Janeiro: Civilização Brasileira.

CARNEIRO, Elizângela dos Santos; CAVALCANTI, Tacina de Lira Cavalcanti. 2017. As barreiras atitudinais do nono modelo de avaliação da pessoa com deficiência para o acesso ao Benefício de Prestação

Anuário Antropológico, volume 44, n.2, 2019, pp.229-260 
Continuada. In: ABATH, Edistia Maria (org.). Proteção social, política de assistência social: reflexão sobre experiências profissionais. Recife: Bagaço.

CARNEIRO, Rosamaria; FLEISCHER, Soraia. 2018. Eu não esperava por isso. Foi um susto: conceber, gestar e parir em tempos de Zika à luz das mulheres de Recife, PE, Brasil. Interface: comunicação, saúde e educação, v. 22, n. 66, p. 709-719.

CARTILHA BPC. s/d. Ministério do Desenvolvimento Social e Combate à Fome - MDS. Disponível em: https: / /www.mds.gov.br/webarquivos/publicacao/assistencia_social/cartilhas/cartilha-bpc-final.pdf Acesso em: 16/08/18.

CARVALHO, Layla Pedreira. 2017. Vírus Zika e Direitos Reprodutivos entre as políticas transnacionais, as nacionais e as ações locais. Cadernos de Gênero e Diversidade, v. 3, n. 2, p. 134-157.

DHANDA, Amita. 2008. Construindo um novo léxico dos direitos humanos: Convenção sobre os Direitos das Pessoas com Deficiências. Sur, Revista Internacional de Direitos Humanos, São Paulo, v. 5, n. 8, p. 42-59.

DINIZ, Debora. 2007. O que é deficiência. São Paulo: Brasiliense.

DINIZ, Debora; BARBOSA, Lívia; SANTOS, Wederson Rufino dos. 2009. Deficiência, direitos humanos e justiça. Sur Revista Internacional de Direitos Humanos, n. 11, p. 65-78.

DINIZ, Debora. 2016b. Vírus Zika e mulheres. Cadernos de Saúde Pública, Rio de Janeiro, v. 32, n. 5, e00046316.

DINIZ, Debora. 2017. Zika em Alagoas: a urgência de direitos. Brasília: Letras Livres.

DINIZ, Debora. 2016a. Zika: do Sertão nordestino à ameaça global. 2016a. Rio de Janeiro: Civilização Brasileira.

FLEISCHER, Soraya. 2017. Segurar, caminhar e falar: notas etnográficas sobre a experiência de uma mãe de micro no Recife-PE. Cadernos de Gênero e Diversidade, v. 3, n. 2, p. 93-112.

GALLI, Beatriz; DESLANDES, Suely. 2016. Ameaças de retrocesso nas políticas de saúde sexual e reprodutiva no Brasil em tempos de epidemia de Zika. Cadernos de Saúde Pública, Rio de Janeiro, v. 32, n. 4, e00031116, p. 1-3.

GARCIA, Leila Posenato. 2018. Epidemia do Vírus Zika e Microcefalia no Brasil: emergência, evolução e enfrentamento. Texto para discussão. Brasília; Rio de Janeiro: Instituto de Pesquisa Econômica Aplicada.

HEYMANN, David L. et al. 2016. Zika virus and microcephaly: why is this situation a PHEIC? The Lancet, v. 387, n. 10020, p. 719-721.

MATOS, Silvana Sobreira de. 2018. Nada sobre nós sem nós: associativismo e deficiência na Síndrome Congênita do ZikaVírus. Trabalho apresentado na $31^{a}$ Reunião Brasileira de Antropologia, GT 36. Etnografias da deficiência, Universidade de Brasília - UnB, Brasília, 03 a 06 de dezembro. (mimeo.).

MATOS, Silvana Sobreira de; LIRA, Luciana Campelo; Meira, Fernanda. 2018. Deficiência Ativismo, Gênero e Cuidado na Síndrome Congênita do Zika Vírus. Revista Anthropológicas, ano 22, v. 29, n. 2, p. $142-153$.

MATOS, Silvana Sobreira de; SILVA, Ana Cláudia Rodrigues da; QUADROS, Marion Teodósio de. 2018. Como a antropologia pode atuar? Diálogo entre pesquisa e assistência no caso da Síndrome Congênita do ZikaVirus em Pernambuco/Brasil. Ethnography of the relationship between citizen and state in the 
context of Zika and other arboviruses. Florianópolis: texto apresentado no $18^{\circ}$ Congresso Mundial IUAES, OP 078 (mimeo.).

MEDEIROS, Marcelo; BARROS, Fábio Granja; NETO, Melchior Sawaya. 2010. Conceito de Família do Benefício de Prestação Continuada. In: DINIZ, Debora; MEDEIROS, Marcelo; BARBOSA, Lívia (orgs.). Deficiência e igualdade. Brasília: LetrasLivres; Editora Universidade de Brasília, p. 111 130.

MELLO, Anahi Guedes de; NUERNBERG, Adriano Henrique. 2012. Gênero e deficiência: interseções e perspectivas. Estudos Feministas, v. 20, n. 3, p. 635-655.

MOON, Suerie et al. 2015. Will Ebola change the game? Ten essential reforms before the next pandemic. The report of the Harvard-LSHTM Independent Panel on the Global Response to Ebola. The Lancet, n. 386, p. 2204-2221.

NETO, Julio Rodrigues Coelho. 2018. VOTO. 0515408-49.2017.4.05.8100S, 31/01.

NUNES, João; PIMENTA, Denise Nacif. 2016. A epidemia de Zika e os limites da saúde global. Lua Nova, São Paulo, n. 98, p. 21-46.

PENALVA, Janaina; DINIZ, Debora; MEDEIROS, Marcelo. 2010. O Benefício de Prestação Continuada no Supremo Tribunal Federal. Revista Sociedade e Estado, v. 25, n. 1.

PINHO, Paula Andréa; PEREIRA, Pedro Paulo Gomes. 2012. Itinerários terapêuticos: trajetórias entrecruzadas na busca por cuidados. Interface (Botucatu), v. 16, n. 41, p. 435-447.

QUADROS, Marion Teodósio de; MATOS, Silvana Sobreira de; SILVA, Ana Cláudia da. 2019. Assistência pública à saúde de bebês com Síndrome Congênita do ZikaVírus durante e após o término do estado de emergência em saúde pública em Pernambuco, Brasil. Comunicação no VII Congresso da Associação Portuguesa de Antropologia. Lisboa (Portugal), Faculdade de Ciências Sociais e Humanas da Universidade Nova Lisboa, 4 a 7 de julho. (mimeo).

SANTOS, Wederson. 2011. Deficiência e BPC: o que muda na vida das pessoas atendidas? Ciência \& Saúde Coletiva, n. 16, Supl. 1, p. 787-796.

SANTOS, Wederson; PENALVA, Janaína. 2010. Renda, idade e corpo para o Benefício de Prestação Continuada. In: DINIZ, Debora; MEDEIROS, Marcelo; BARBOSA, Lívia (orgs.). Deficiência e igualdade. Brasília: LetrasLivres: Editora Universidade de Brasília, p. 131-150.

SANTOS, Wederson. 2010a. Assistência social e deficiência no Brasil: o reflexo do debate internacional dos direitos das pessoas com deficiência. Serviço Social em Revista, v. 13, n. 1, p. 80-101.

SANTOS, Wederson. 2010b. O que é incapacidade para a proteção social brasileira? In: DINIZ, Debora; MEDEIROS, Marcelo; BARBOSA, Lívia (orgs.). Deficiência e igualdade. Brasília: LetrasLivres; Editora Universidade de Brasília, p. 173-192.

SANTOS, Wederson. 2015. Modelo social, interdisciplinaridade e intersetorialidade: desafios às políticas sociais para a deficiência no Brasil. Brasília: UnB/Fundação Oswaldo Cruz. (Observatório Internacional de Capacidades Humanas, Desenvolvimento e Políticas Públicas, n. 2).

SANTOS, Wederson. 2016. Deficiência como restrição de participação social: desafios para avaliação a partir da Lei Brasileira de Inclusão. Ciência \& Saúde Coletiva, v. 21, n. 10, p. 3007-3015.

SANTOS, Wederson; DINIZ, Debora, PEREIRA, Natália. 2010. Deficiência e perícia médica: os contornos do corpo. In: DINIZ, Debora, MEDEIROS, Marcelo; BARBOSA, Lívia (orgs.). Deficiência e 
igualdade. Brasília: LetrasLivres; Editora Universidade de Brasília, p. 151-172.

SCOTT, Russell Parry et al. 2018. Itinerários terapêuticos, cuidados e atendimento na construção de ideias sobre maternidade e infância no contexto da Zika. Interface (Botucatu), v. 22, n. 66, p. 673-684.

SCOTT, Russell Parry et al. 2017. Epidemia de Zika e as articulações das mães num campo tensionado entre feminismo, deficiência e cuidados. Cadernos Gênero e Diversidade, v. 3, n. 2, p. 73-92.

SILVA, Ana Cláudia Rodrigues da; MATOS, Silvana Sobreira de; QUADROS, Marion Teodósio de. 2017. Economia política do Zika: realçando relações entre Estado e cidadão. Revista Anthropológicas, v. 28, n. 1, p. 223-246.

SOUZA, Anayara Raissa Pereira de; VITORINO, Bruna de Melo; GIAQUETO, Adriana. 2016. A perícia social como possibilidade de acesso ao BPC na esfera judicial. IV SIMPÓSIO MINEIRO DE ASSISTENTES SOCIAIS, p. 1-14.

VAITSMAN, Jeni; LOBATO, Lenaura de Vasconcelos Costa. 2017. Benefício de Prestação Continuada (BPC) para pessoas com deficiência: barreiras de acesso e lacunas intersetoriais. Ciência \& Saúde Coletiva, v. 22, n. 11 , p. $3527-3536$.

VENTURA, Deisy de Freitas Lima. 2016. Do Ebola ao Zika: as emergências internacionais e a securitização da saúde global. Cadernos de Saúde Pública, v. 32, n. 4, p. 1-4. 
Resumo: O estado de emergência em saúde pública decorrente da epidemia do Zika vírus no Brasil, especificamente na Região Nordeste e no Estado de Pernambuco, mobilizou o sistema de saúde, da assistência social, o campo científico e jurídico, num esforço conjunto para responder à população e as agências internacionais sobre o nascimento de crianças com microcefalia (Síndrome Congênita do Zika Vírus SCZ). Neste artigo, fazemos uma análise do Benefício de Prestação Continuada BPC, a partir da lei que priorizou o seu acesso a crianças acometidas pelo Zika Vírus no Instituto Nacional do Seguro Social - INSS. A partir do método etnográfico, buscamos compreender as particularidades relacionadas à Emergência em Saúde Pública e ao modelo social de deficiência, sob a influência do BCP, que entram em pauta para o entendimento da epidemia. Em seguida, abordamos como se dão as negociações dos diferentes atores do processo - famílias atingidas pela SCZ, INSS, judiciário no acesso ou não ao BPC e evidenciamos que a deficiência tem sido relativizada em detrimento do critério da pobreza.

Palavras-chave: Zika; Síndrome Congênita do Zika Vírus - SCZ; deficiência; Benefício de Prestação Continuada; Estado.
Abstract: The state of emergency in public health due to the Zika virus epidemic in Brazil, specifically in the Northeast Region and in Pernambuco state, mobilized the health system, social assistance, scientific and legal field, in a joint effort to respond to the population and international agencies on the birth of children with microcephaly (Congenital Zika Virus Syndrome - SCZ). In this article, we analyze the Continuing Care Benefit - BPC, based on the law that prioritized its access to children affected by the Zika Virus at the National Institute of Social Security (INSS). Based on the ethnographic method, we sought to understand the particularities related to the Public Health Emergency and to the social model of disability, under the influence of the BCP, which are part of the understanding of the epidemic. Next, we discuss how the different actors in the process - families affected by the SCZ, INSS, and judiciary deal with access to the BPC and show that disability has been relativized to the detriment of the poverty criterion.

Keywords: Zika; Congenital Zika Virus Syndrome - SCZ; disability; Benefit of Continuing Care; State. 